\title{
Immunomodulatory properties of characellide A on human peripheral blood mononuclear cells
}

\author{
Simone Marcella ${ }^{1} \cdot$ Sam Afoullouss ${ }^{2,3} \cdot$ Olivier P. Thomas $^{2} \cdot$ A. Louise Allcock ${ }^{3} \cdot$ Paul V. Murphy $^{4}$. \\ Stefania Loffredo ${ }^{1,5}$ (i)
}

Received: 15 April 2021 / Accepted: 16 June 2021 / Published online: 9 July 2021

(c) The Author(s) 2021

\begin{abstract}
Marine sponges and their associated microbiota are multicellular animals known to produce metabolites with interesting pharmacological properties playing a pivotal role against a plethora of pathologic disorders such as inflammation, cancer and infections. Characellide A and B belong to a novel class of glycolipopeptides isolated from the deep sea marine sponge Characella pachastrelloides. In this study, we have evaluated the effects of characellide A and B on cytokine and chemokine release from human peripheral blood mononuclear cells (PBMC). Characellide A induces a concentration- and time-dependent CXCL8, IL-6 and TNF- $\alpha$ release from PBMC. This production is mediated by the induction of gene transcription. Moreover, cytokine/chemokine release induced by characellide A from PBMC is CD1d-dependent because a CD1d antagonist, 1,2-bis(diphenylphosphino)ethane [DPPE]-polyethylene glycolmonomethylether [PEG], specifically inhibits characellide A-induced activation of PBMC. In conclusion, characellide A is a novel modulator of adaptative/innate immune responses. Further studies are needed to understand its potential pharmacological application.
\end{abstract}

Keywords IL- $6 \cdot$ TNF- $\alpha \cdot$ Simplexide $\cdot$ CD1d $\cdot$ LPS

\begin{tabular}{|c|c|}
\hline \multicolumn{2}{|c|}{ Abbreviations } \\
\hline$\alpha$-GalCer & $\alpha$-Galactosylceramide \\
\hline CD1d & Cluster of differentiation-1d \\
\hline CXCL8 & $\mathrm{C}-\mathrm{X}-\mathrm{C}$ motif ligand 8 \\
\hline DCF & 20,70-Dichlorofluorescein \\
\hline DPPE-PEG & $\begin{array}{l}\text { 1,2-Bis(diphenylphosphino)ethane-polyeth- } \\
\text { ylene glycolmonomethylether }\end{array}$ \\
\hline
\end{tabular}

Stefania Loffredo

stefanialoffredo@hotmail.com; stefania.loffredo2@unina.it

1 Department of Translational Medical Sciences, Center for Basic and Clinical Immunology Research (CISI), WAO Center of Excellence, University of Naples Federico II, Via S. Pansini 5, 80131 Naples, Italy

2 Marine Biodiscovery, School of Chemistry, Ryan Institute, National University of Ireland Galway (NUI Galway), University Road, Galway H91TK33, Ireland

3 Zoology Department, School of Natural Sciences, Ryan Institute, National University of Ireland Galway (NUI Galway), University Road, Galway H91TK33, Ireland

4 School of Chemistry, National University of Ireland Galway, University Road, Galway H91 TK33, Ireland

5 Institute of Experimental Endocrinology and Oncology "G. Salvatore", National Research Council, Naples, Italy
GAPDH Glyceraldehyde 3-phosphate dehydrogenase $\mathrm{H}_{2}$ DCFDA $\quad 2^{\prime}, 7^{\prime}$-Dichlorodihydrofluorescein diacetate IFN- $\gamma \quad$ Interferon- $\gamma$ IL-4 Interleukin-4

IL-6 Interleukin-6

IL-10 Interleukin-10

iNKT Invariant natural killer T cells

LPS Lipopolysaccharide

PBMC Peripheral blood mononuclear cells

ROS Reactive oxygen species

TFA Trifluoroacetic acid

TNF- $\alpha \quad$ Tumor necrosis factor- $\alpha$

\section{Introduction}

Marine sponges are sessile multicellular animals characterized by a soft and sessile body (Anjum et al. 2016). Being unable to move and having limited physical defenses, many marine sponges have developed a sophisticated chemical defense system to protect themselves from predators and to avoid fouling by other marine organisms (Hertiani et al. 2010; Thomas et al. 2010). Given their ability to produce small metabolites, marine sponges have been the subject 
of much research which has identified thousands of different natural products including 300 novel compounds with interesting pharmacological features (Faulkner 2000, 2001, 2002; Sipkema et al. 2005; Blunt et al. 2006; Mehbub et al. 2014). Interestingly, some of the sponge-derived metabolites have been included in clinical and preclinical trials showing their efficacy as anti-inflammatory (Alcaraz and Paya 2006), antitumoral (Negi et al. 2017), immunosuppressive (Gunasekera et al. 1989), neurosuppressive (Yurchenko et al. 2020), antiviral (Sagar et al. 2010), antimalarial (Fattorusso and Taglialatela-Scafati 2009), antibiotic (Bibi et al. 2017) or antifungal (Karpinski 2019) compounds. Glycolipids represent the main components of several marine organisms and have been identified as potent activators of immune cells by binding to CD1d molecule (Wu et al. 2008). CD1d is a MHC-like presenting antigen molecule, belonging to the CD1 family, expressed on immune cells including monocytes, macrophages, dendritic cells B lymphocytes, thymocytes but not mature T cells (Exley et al. 2000; Brigl and Brenner 2004). It is also expressed in non-hematopoietic cells such as epithelial and vascular smooth muscle cells (Canchis et al. 1993). CD1d binds and presents lipid antigens to natural killer $\mathrm{T}$ cells with an invariant $\mathrm{T}$ cell receptor alpha chain (iNKT) inducing their development and activation in several pathological conditions such as infection (Skold and Behar 2003), autoimmune disorders (Mars et al. 2008), allergic responses (Lexmond et al. 2014) and tumor immunity ( $\mathrm{Ni}$ et al. 2015). It has been demonstrated that CD1d binds $\alpha$-galactosylceramide ( $\alpha$-GalCer) and simplexide, two glycolipids isolated from the marine sponges Agelas mauritiana and Plakortis simplex respectively (Koch et al. 2005; Loffredo et al. 2014). It was discovered that $\alpha$-GalCer induced Th1 (IFN- $\gamma$ ) and Th2 (IL-4) cytokine production from human NKT cells in a CD1d-dependent manner (Kawano et al. 1997; Kronenberg 2005). Simplexide activated human monocytes through CD1d-producing cytokines and chemokines and showed a proinflammatory profile (Loffredo et al. 2014). Two metabolites belonging to a new class of glycolipopeptides, namely characellide A and $\mathrm{B}$, were recently isolated from the deep sea marine sponge Characella pachastrelloides. Both characellides were first shown to inhibit reactive oxygen species (ROS) production from microglia BV-2 cell line stimulated with Lipopolysaccharide (LPS), therefore acting as anti-inflammatory mediators (Afoullouss et al. 2019). To date, there are no studies on the effects of characellides on primary immune cells. In this work, we investigated the effects of characellides A and B on human peripheral blood mononuclear cells (PBMC) and we tried to understand their mechanism of action.

\section{Materials and methods}

\section{Reagents}

The following were used for the experiments: L-glutamine (Sigma-Aldrich ${ }^{\circledR} 155$ St. Louis, MO, USA), antibiotic-antimycotic solution (10.000 IU/ml penicillin, $10 \mathrm{mg} /$ $\mathrm{ml}$ streptomycin, and $25 \mu \mathrm{g} / \mathrm{ml}$ amphotericin B) (Lonza, Basel, CH), MEM non-essential amino acids (Microgem ${ }^{\circledR}$, Naples, Italy), fetal bovine serum (FBS) (Sigma-Aldrich ${ }^{\circledR}$ 155 St. Louis, MO, USA), RPMI 1640 (Microgem ${ }^{\circledR}$, Naples, Italy), Histopaque-1077 (GE Healthcare Bio-Sciences AB SE-751 84 Uppsala, Sweden), detoxified LPS (from Escherichia coli serotype 026:B6) (Sigma-Aldrich ${ }^{\circledR}$ 155 St. Louis, MO, USA), 1,2-Bis (diphenylphosphino) ethane [DPPE]-polyethylene glycolmonomethylether [PEG] was from Avanti Polar Lipids (Alabaster, AL). Simplexide was isolated from Plakortis simplex at the Department of Pharmacy, University of Naples Federico II. Target-specific primers for $C X C L 8, I L 6, T N F \alpha$, and $G A P D H$ were designed using the Beacon Designer 3.0 (Biorad Laboratories, Milan, Italy) and produced and purified by Custom Primers (Life Technologies, Milan, Italy).

\section{Characellide A and B isolation}

The freeze-dried sponge biomass ( $330 \mathrm{~g})$ was extracted with $\mathrm{MeOH}-\mathrm{CH}_{2} \mathrm{Cl}_{2}$ (1:1) using ultra-sonification. Crude extract $(20.6 \mathrm{~g})$ was fractionated into five fractions utilizing RP-C18 vacuum liquid chromatography, of decreasing polarity gradient, from $\mathrm{H}_{2} \mathrm{O}, \mathrm{H}_{2} \mathrm{O}-\mathrm{MeOH}(1: 1)$, $\mathrm{H}_{2} \mathrm{O}-\mathrm{MeOH}(1: 3), \mathrm{MeOH}$ and $\mathrm{MeOH}-\mathrm{CH}_{2} \mathrm{Cl}_{2}$ (1:1). The $\mathrm{MeOH}$ fraction $(628 \mathrm{~g})$ was purified using RP-HPLC on a semi-preparative T3 column, $250 \mathrm{~mm} \times 19 \mathrm{~mm}, 5 \mu \mathrm{m}$ (Xselect, Waters, Milford, CT, USA), using water (A) and acetonitrile (B) as mobile phases, both acidified with $0.1 \%$ Trifluoroacetic acid (TFA), with a flow of $5 \mathrm{ml} / \mathrm{min}$. The column was eluted with $45 \%$ B for 5 min, then a linear gradient $68 \% \mathrm{~B}$ over $12 \mathrm{~min}$ was performed, finally, the column was eluted at $68 \% \mathrm{~B}$ for a further $15 \mathrm{~min}$. Subfraction 2 containing both characellide $\mathrm{A}$ and $\mathrm{B}$, was collected at $6 \mathrm{~min}\left(t_{\mathrm{R}} 6 \mathrm{~min}, 3.7 \mathrm{mg}\right)$. This mixture was then further purified utilizing BEH amide $4.6 \mathrm{~mm} \times 250 \mathrm{~mm}$, $5 \mu \mathrm{m}$ (Xbridge, Waters, Milford, CT, USA), using isocratic mobile phase conditions of water (A) and acetonitrile (B, $89 \%$ ) both acidified with $0.1 \%$ TFA, with a flow rate of $1 \mathrm{ml} / \mathrm{min}$, yielding characellide $\mathrm{A}\left(t_{\mathrm{R}} 10 \mathrm{~min}, 2.2 \mathrm{mg}\right)$ and $\mathrm{B}\left(t_{\mathrm{R}} 14 \mathrm{~min}, 0.8 \mathrm{mg}\right)$. Identification of characellide $\mathrm{A}$ and $\mathrm{B}$ was determined from a comparison of published and experimental using nuclear magnetic resonance spectroscopy (NMR) data, measured at $600 \mathrm{MHz}$ equipped with 
a cryoprobe (Agilent DD2 NMR $600 \mathrm{MHz} 54 \mathrm{~mm}$ ) and High-Resolution Electrospray Ionisation Mass Spectrometry (HRESIMS) data from a qToF Agilent 6540 in $\operatorname{ESI}(+)$.

Characellide A: Yellowish oily solid; [ $\alpha] \mathrm{D}-30$ (c 0.1, $\mathrm{MeOH}) ; \lambda \max (\log s) 225(4.24) \mathrm{nm} ;{ }^{1} \mathrm{H}-\mathrm{NMR}$ and ${ }^{13} \mathrm{C}-$ NMR data, see Table S1. HRESIMS $m / z 867.4705[\mathrm{M}+\mathrm{H}]^{+}$ (867.4710 calcd. For $\mathrm{C}_{41} \mathrm{H}_{67} \mathrm{~N}_{6} \mathrm{O}_{14}, \Delta-0.6 \mathrm{ppm}$ ).

Characellide B: Yellowish oily solid; [ $\alpha] \mathrm{D}-60$ (c 0.1 , $\mathrm{MeOH}) ; \lambda \max (\log s) 225(4.24) \mathrm{nm} ;{ }^{1} \mathrm{H}-\mathrm{NMR}$ and ${ }^{13} \mathrm{C}-$ NMR data see Table S1. HRESIMS $m / z 867.4700[\mathrm{M}+\mathrm{H}]^{+}$ (867.4710 calcd. For $\mathrm{C}_{41} \mathrm{H}_{67} \mathrm{~N}_{6} \mathrm{O}_{14}, \Delta-1.1 \mathrm{ppm}$ ).

\section{Isolation and purification of peripheral blood mononuclear cells (PBMC)}

The study protocol involving the use of human blood cells was approved by the Ethical Committee of the University of Naples Federico II, and written informed consent was obtained from blood donors in accordance with the principles expressed in the Declaration of Helsinki (Protocol number 301/12). PBMC were isolated from buffy coats of healthy donors (HBsAg - , HCV - , and HIV -) obtained from a leukapheresis unit. Leukocytes were separated from erythrocytes by dextran sedimentation. PBMC were purified by Histopaque- 1077 density gradient centrifugation $(400 \times g$ for $20 \mathrm{~min}$ at $22^{\circ} \mathrm{C}$ ) and resuspended in RPMI 1640 supplemented with 5\% FBS, 2 mmol/l L-glutamine, antibiotic-antimycotic solution and non-essential amino acid. Finally, the cells were used for experiments.

\section{Cell cultures}

Characellide A and B preparations were routinely checked for LPS contamination. In particular, characellide $(10 \mu \mathrm{g} / \mathrm{ml})$ and LPS $(100 \mathrm{ng} / \mathrm{ml})$ were preincubated $\left(37^{\circ} \mathrm{C}, 30 \mathrm{~min}\right)$ with polymyxin B $(50 \mu \mathrm{g} / \mathrm{ml})$ (Sigma-Aldrich ${ }^{\circledR} 155$ St. Louis, MO, USA) before addition to the cells. Since characellide is not well soluble in DMSO, all experiments were done in polystyrene plates coated with various concentrations of compounds dissolved in methanol. Solvent was dried under nitrogen immediately before the addition of cells. PBMC $\left(2 \times 10^{6}\right.$ cells per well) were incubated $\left(37^{\circ} \mathrm{C}, 5 \% \mathrm{CO}_{2}\right.$, $16 \mathrm{~h}$ ) in 48-well polystyrene plates precoated with methanol alone or increased concentrations of characellide $A$ and B $(0.3-10 \mu \mathrm{g} / \mathrm{ml})$ or simplexide $(10 \mu \mathrm{g} / \mathrm{ml})$. PBMC $\left(2 \times 10^{6}\right.$ cells per well) were preincubated $\left(37^{\circ} \mathrm{C}, 5 \% \mathrm{CO}_{2}, 30 \mathrm{~min}\right)$ with increasing concentrations of DPPE-PEG $(0.05-10 \mu \mathrm{g} /$ $\mathrm{ml})$ and then stimulated $\left(37{ }^{\circ} \mathrm{C}, 5 \% \mathrm{CO}_{2}, 16 \mathrm{~h}\right)$ with LPS $(100 \mathrm{ng} / \mathrm{ml})$, simplexide $(10 \mu \mathrm{g} / \mathrm{ml})$ and characellide A $(10 \mu \mathrm{g} / \mathrm{ml})$. At the end of the experiments, the supernatants were removed, centrifuged $\left(300 \times g, 4{ }^{\circ} \mathrm{C}, 5 \mathrm{~min}\right)$ and stored at $-80{ }^{\circ} \mathrm{C}$ for subsequent determination of CXCL8, IL-6, TNF- $\alpha$ and IL- 10 release. The kinetics of CXCL8, IL- 6 and
TNF- $\alpha$ release and mRNA expression in PBMC were also performed. Therefore cells $\left(2 \times 10^{6}\right.$ cells per well) were incubated $\left(37{ }^{\circ} \mathrm{C}, 5 \% \mathrm{CO}_{2}\right)$ at different times $(2,4,8,14,18$ and $24 \mathrm{~h})$ with characellide $\mathrm{A}(10 \mu \mathrm{g} / \mathrm{ml})$ and supernatants were collected, centrifuged $\left(300 \times g, 4{ }^{\circ} \mathrm{C}, 5 \mathrm{~min}\right)$ and stored at $-80{ }^{\circ} \mathrm{C}$ for subsequent determination of CXCL8, IL-6 and TNF- $\alpha$ release. PBMC incubated $\left(37^{\circ} \mathrm{C}, 5 \% \mathrm{CO}_{2}\right.$, ) for 2,4 and $8 \mathrm{~h}$ were lysed to evaluate CXCL8, IL- 6 and TNF- $\alpha$ mRNA expression.

\section{Apoptosis assay}

Purified PBMC $\left(10^{6}\right.$ cells $\left./ \mathrm{ml}\right)$ were cultured in an characellide A $(10 \mu \mathrm{g} / \mathrm{ml}), B(10 \mu \mathrm{g} / \mathrm{ml})$, Simplexide $(10 \mu \mathrm{g} / \mathrm{ml})$ and LPS $(100 \mathrm{ng} / \mathrm{ml})$ for $18 \mathrm{~h}$. PBMC were stained with FITCconjugated annexin $\mathrm{V}$ and propidium iodide (PI), according to the protocol provided by the manufacturer (Miltenyi Biotec). Quantification was performed using a MACSQuant flow cytometer (Miltenyi Biotec). Live cells were assumed to be double-negative annexin V2PI2 cells. Analysis was performed using the FlowJo v.10.

\section{ELISA assay}

The release of CXCL8, IL- 6 and TNF- $\alpha$ and IL-10 in the culture supernatant was measured in duplicate determinations by commercially available ELISA kits (R\&D, Minneapolis, MN USA) according to the manufacturer's instructions. The results were normalized for the number of cells per well. CXCL8 release was expressed as $n g / 10^{6}$ cells whereas IL- 6 and TNF- $\alpha$ were expressed as pg $/ 10^{6}$ cells.

\section{RT-PCR}

Total RNA was extracted by TRIzol reagent (Euroclone ${ }^{\circledR}$, Pero, Milan, Italy) following the manufacturer's instructions. RNA quality and integrity were estimated by spectrophotometric analysis on a Nanodrop ND-1000 spectrophotometer (Thermo Scientific, Wilmington, DE, USA). Reverse transcription was performed using the High-Capacity cDNA Reverse Transcription Kit (Applied Biosystems, Foster City CA, USA). Real-time RT-PCR was performed by means of Universal SYBR Green Supermix (Bio-Rad) on a CFX96 Real-time detection system (BioRad). GAPDH was used as housekeeping gene to normalize $\mathrm{Ct}$ (cycle threshold) values using the $2^{-\Delta \mathrm{Ct}}$ formula. PCR efficiency and specificity were evaluated by analyzing amplification curves with serial dilutions of the template cDNA and their dissociation curves. Each cDNA sample was analyzed in triplicate and the corresponding no-RT mRNA sample was included as a negative control. The data were analyzed with iCycler iQ analysis software (Biorad) and the changes in CXCL8, IL6 and TNF $\alpha$ mRNAs were expressed as $2^{-\Delta \mathrm{Ct}}$. 


\section{Reactive oxygen species (ROS) production}

PBMC were incubated for $30 \mathrm{~min}$ after the addition of $10 \mu \mathrm{g} / \mathrm{ml}$ H2DCF-DA (Life Technologies, Milan, Italy). H2DCF-DA is a fluorogenic dye that allows the evaluation of hydroxyl peroxyl and other ROS activities within the cell. Once diffused into the cell, H2DCF-DA is deacetylated by cellular esterases to a nonfluorescent molecule, which is oxidized by ROS into 20, 70 dichlorofluorescein (DCF). This latter is highly fluorescent and can be determined by fluorescence spectroscopy with maximum excitation and emission wavelengths of 492-495 and 517-527 nm, respectively. The first group of cells was washed in phosphate buffer saline (PBS), then resuspended in RPMI supplemented with 5\% of FBS and finally seeded in a 96-well precoated plate with methanol alone, characellide A or B $(10 \mu \mathrm{g} / \mathrm{ml})$ or stimulated with LPS $(100 \mathrm{ng} / \mathrm{ml})$. The second group of PBMC was preincubated $\left(37{ }^{\circ} \mathrm{C}, 5 \% \mathrm{CO}_{2}, 1 \mathrm{~h}\right)$ with characellide A or $\mathrm{B}$ and then stimulated with LPS. Finally, immediately after LPS stimulation, the plates were placed in an EnSpire Multimode Plate Reader (Perkin Elmer). The ability of stimuli to induce cytoplasmic ROS-catalyzed oxidation of DCFH in PBMC was measured as compared to the negative control (the medium alone). The data were expressed as DCF mean fluorescence intensity (MFI) measured up to $50 \mathrm{~min}$ with $10 \mathrm{~min}$ span at an excitation wavelength of $492-495 \mathrm{~nm}$ and emission at $517-527 \mathrm{~nm}$.

\section{Statistical analysis}

The data are expressed as mean values \pm SEM of the indicated number of experiments. Statistical analysis was performed in Prism 6 (Graph-Pad Software). Statistical analysis was performed by Student's $t$ test or one-way analysis of variance followed by Dunnett's test (when comparison was made against a control) or Bonferroni's test (when comparison was made between each pair of groups) by means of Analyse-it for Microsoft Excel, version 2.16 (Analyse-it Software, Ltd., Leeds, United Kingdom). Statistically significant differences were accepted when the $p$ value was at least $\leq 0.05$.

\section{Results}

\section{Characellide-A induces the production of CXCL8, IL-6 and TNF-a from human PBMC}

In the first part of the experiments, we evaluated the effects of characellide A and B on cytokine and chemokine release from human PBMC. The effect of compounds on cell viability was checked. Cells were incubated $\left(37^{\circ} \mathrm{C}, 5 \% \mathrm{CO}_{2}, 16 \mathrm{~h}\right)$ with increasing concentrations $(0.3-10 \mu \mathrm{g} / \mathrm{ml})$ of characellide
A and B and the release of CXCL8, IL-6, TNF- $\alpha$ and IL-10 was determined by ELISA. We used the glycolipid simplexide isolated from the marine sponge Plakortis simplex as a positive control (Vintonyak et al. 2008). Figure 1 shows that characellide A, but not B, induced CXCL8 (Fig. 1A), IL-6 (Fig. 1B) and TNF- $\alpha$ (Fig. 1C) from PBMC. CXCL8 and IL-6 release was significantly increased from $3 \mu \mathrm{g} / \mathrm{ml}$ onwards, while TNF- $\alpha$ release was significant only at a concentration of $10 \mu \mathrm{g} /$ $\mathrm{ml}$. Conversely, both characellides A and B did not induce IL-10 release from human PBMC (Fig. 1D). The production of TNF- $\alpha$ induced by characellide A was comparable to that of simplexide $(10 \mu \mathrm{g} / \mathrm{ml})$, our positive control, whereas the release of IL- 6 and TNF- $\alpha$ was lower (Fig. 1A-C). To exclude that the effect of characellide could be due to LPS contamination, a well-characterized stimulus for these cells (Loffredo et al. 2014), PBMC were stimulated with characellide in the presence of polymyxin $B(50 \mathrm{mg} / \mathrm{ml})$, a potent inactivator of LPS (Kolomaznik et al. 2018). Polymyxin B did not influence the capacity of characellide A to induce the release of CXCL8, IL-6, and TNF- $\alpha$, whereas it almost completely suppressed the production of cytokines and chemokines induced by LPS (Table 1).

In the next group of experiments, we examined the kinetics of CXCL8, IL- 6 and TNF- $\alpha$ release from PBMC stimulated with an optimal concentration of characellide $\mathrm{A}(10 \mu \mathrm{g} /$ $\mathrm{ml}$ ). Figure 2 reports that CXCL8 (Fig. 2A) release began after $8 \mathrm{~h}$ and reached a plateau after $14 \mathrm{~h}$. Moreover, characellide A-induced release of IL- 6 and TNF- $\alpha$ (Fig. 2B, C) was slower, starting at $14 \mathrm{~h}$ keeping a steady state up to $24 \mathrm{~h}$. These distinct kinetics outcomes of characellide A on PBMC shown in Fig. 2 A-C suggest that the release of these mediators may be due to de novo gene expression rather than to secretion of preformed CXCL8, IL-6 and TNF-a from intracellular stores. Thus, we examined whether characellide A activated cytokine/chemokine gene expression in PBMC by real-time quantitative PCR. The kinetics of induction was quite different. The mRNA expression of CXCL8 (Fig. 2D) and $I L 6$ (Fig. 2E) induced by characellide A were rapid and began after $2 \mathrm{~h}$. In particular, CXCL 8 mRNA peaked at $4 \mathrm{~h}$ and declined after $8 \mathrm{~h}$ whereas $I L 6 \mathrm{mRNA}$ reached a plateau after $4 \mathrm{~h}$. $T N F a$ mRNA was first evident at $4 \mathrm{~h}$ and progressively increased up to $8 \mathrm{~h}$ (Fig. 2F). In support of these results, fresh PBMC did not contain preformed CXCL8, IL-6 and TNF- $\alpha$ (data not shown). These data indicate that characellide A induces a proinflammatory profile by cytokine/chemokine production and gene expression from human PBMC in a time-dependent manner.

\section{CD1d is required for PBMC activation induced by characellide $A$}

CD1d is known to be the most important target of some metabolites isolated from marine sponges including 
A
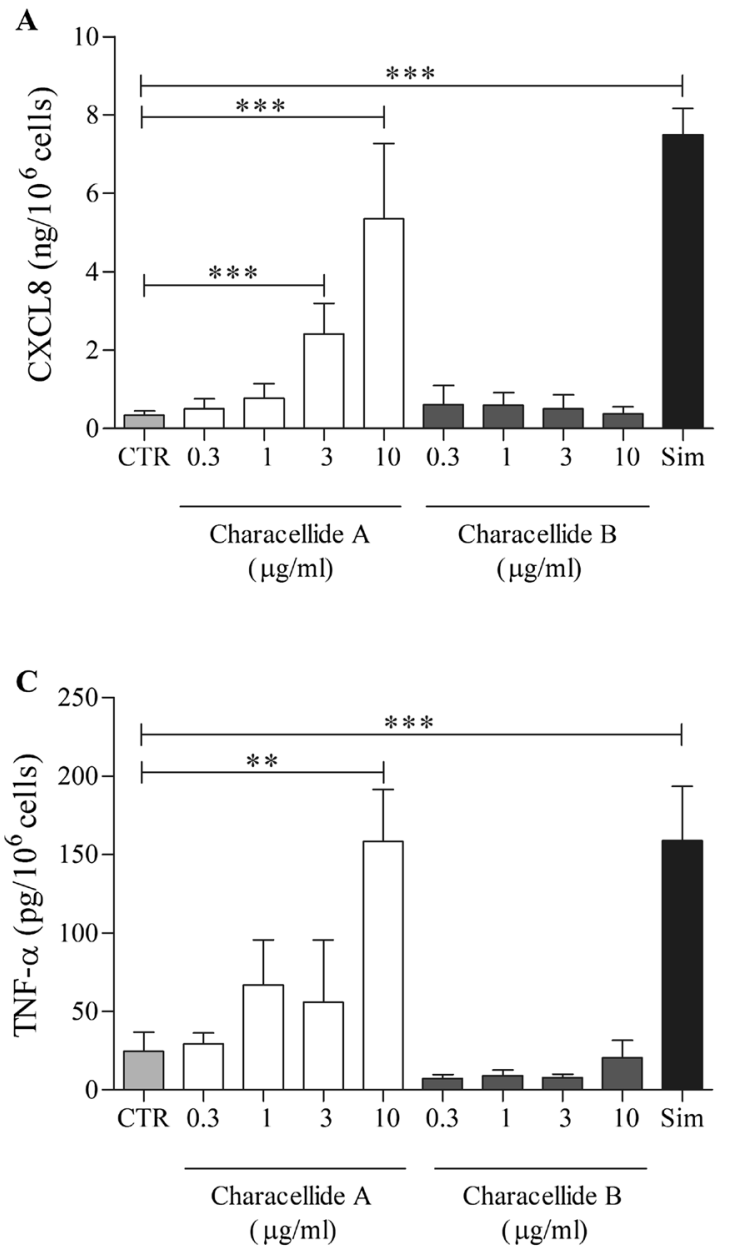

Fig. 1 Effects of characellide A and B on CXCL8, IL-6, TNF- $\alpha$ and IL-10 release from peripheral blood mononuclear cells (PBMC). Polystyrene plates were coated with methanol alone or indicated concentrations of glycolipids dissolved in methanol. Solvent was airdried immediately before the addition of cells. PBMC were incubated $\left(37{ }^{\circ} \mathrm{C}, 5 \% \mathrm{CO}_{2}, 16 \mathrm{~h}\right)$ with medium alone (CTR), characellide A and $\mathrm{B}$ or $10 \mu \mathrm{g} / \mathrm{ml}$ simplexide (Sim). At the end of incubation, the
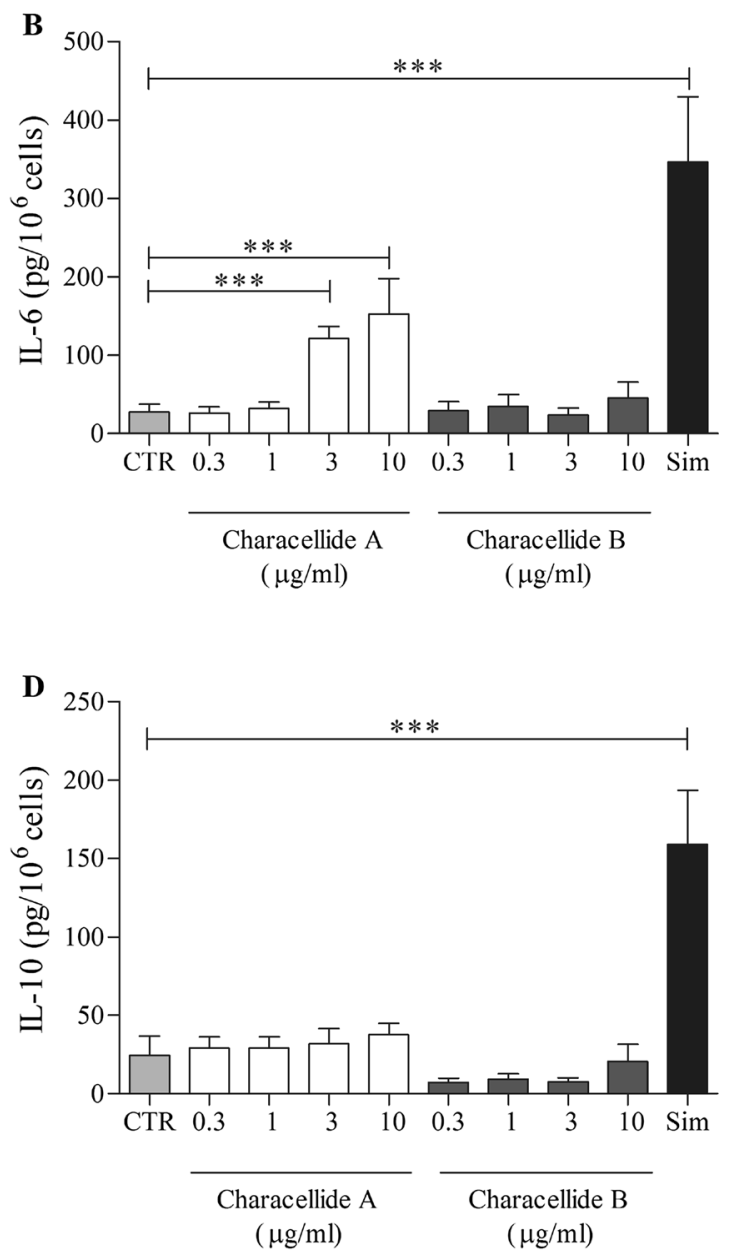

supernatants were collected and centrifuged $\left(300 \times g, 4{ }^{\circ} \mathrm{C}, 5 \mathrm{~min}\right)$. Cytokines and chemokines were determined by ELISA. The values are expressed as ng [for CXCL8 (A)] and pg [for IL-6 (B), TNF- $\alpha(\mathbf{C})$ and IL-10 (D)] per $10^{6}$ of total cells. Data are representative of five independent experiments obtained from different donors. ${ }^{*} p<0.05$, $* * p<0.01, * * * p<0.001$
Table 1 Effect of polymixin B on characellide A- and LPSinduced release of CXCL8, IL-6 and TNF- $\alpha$ from PBMC

\begin{tabular}{llll}
\hline & CXCL8 (ng/10 cells) & IL-6 (pg/10 cells) & TNF- $\alpha\left(\mathrm{pg} / 10^{6}\right.$ cells $)$ \\
\hline CTR & $0.34 \pm 0.10$ & $27.83 \pm 10.03$ & $24.35 \pm 12.34$ \\
Characellide A & $5.35 \pm 1.91^{*}$ & $152.6 \pm 45.14^{*}$ & $158.4 \pm 33.06^{*}$ \\
LPS & $35.36 \pm 0.98^{*}$ & $4346 \pm 10.45^{*}$ & $580.5 \pm 119.3^{*}$ \\
Polymyxin B & $0.45 \pm 0.60$ & $30.47 \pm 9.06$ & $22.53 \pm 10.44$ \\
Characellide A + polymyxin B & $8.31 \pm 2.76^{*}$ & $163.1 \pm 15.10^{*}$ & $163.7 \pm 15.34 *$ \\
LPS + polymyxin B & $10.63 \pm 0.17^{* *}$ & $240.5 \pm 24.40^{* *}$ & $55.28 \pm 5.92^{* *}$
\end{tabular}

PBMC were incubated $\left(37^{\circ} \mathrm{C}, 5 \% \mathrm{CO}_{2}, 16 \mathrm{~h}\right)$ with Characellide A $(10 \mu \mathrm{g} / \mathrm{ml})$ or LPS $(100 \mathrm{ng} / \mathrm{ml})$ either in the absence (CTR) or the presence of polymyxin B $(50 \mu \mathrm{g} / \mathrm{ml})$. Data are the mean \pm SE of three experiments obtained from different donors

$* p<0.001$ versus respective untreated (CTR)

$* * p<0.001$ versus LPS alone 
A

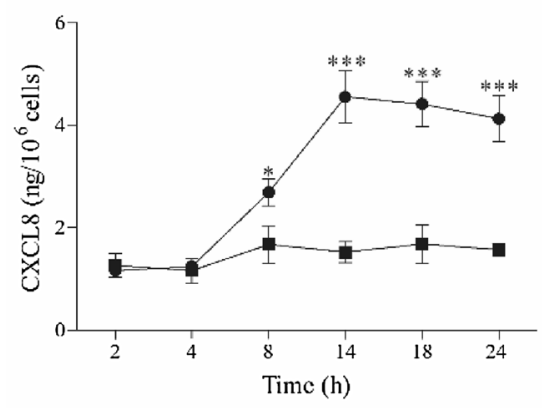

B

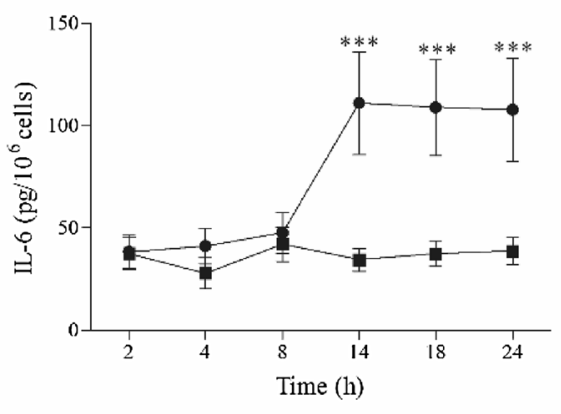

C

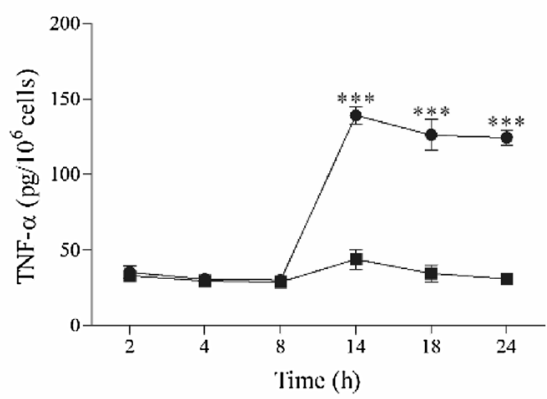

CTR $\bullet$ Characellide A
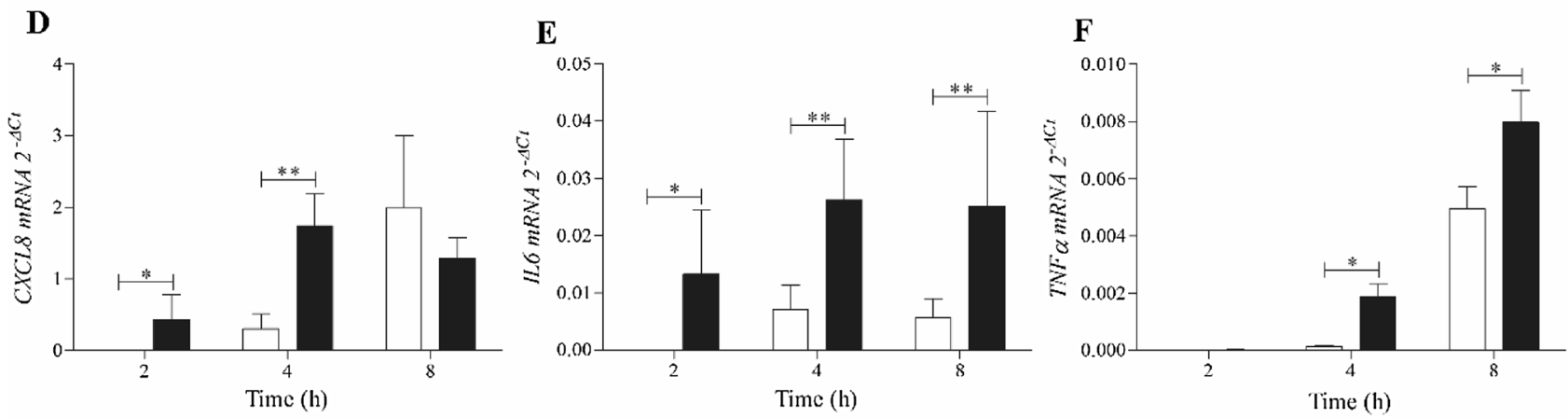

CTR

Fig. 2 Kinetics of CXCL8, IL-6 and TNF- $\alpha$ release and mRNA expression induced by characellide A in PBMC. Polystyrene plates were coated with methanol alone or characellide A $(10 \mu \mathrm{g} / \mathrm{ml})$ dissolved in methanol. Solvent was air-dried immediately before the addition of cells. Cells were incubated $\left(37{ }^{\circ} \mathrm{C}, 5 \% \mathrm{CO}_{2}\right)$ at indicated times with medium alone (CTR) or characellide A. At the end of incubation the supernatants were collected and centrifuged $\left(300 \times g, 4{ }^{\circ} \mathrm{C}, 5 \mathrm{~min}\right)$ and the cells were lysed as described in Meth-

simplexide (Loffredo et al. 2014). We hypothesized that characellide A could be involved in PBMC activation through the CD1d pathway. To evaluate whether DPPEPEG, a CD1d antagonist, was able to inhibit the cytokine and chemokine release from human PBMC induced by characellide, we preincubated $\left(37^{\circ} \mathrm{C}, 5 \% \mathrm{CO}_{2}, 30 \mathrm{~min}\right)$ the cells with DPPE-PEG, and then seeded in precoated plates with characellide A. Figure 3 shows that DPPE-PEG $(0.05-10 \mu \mathrm{g} / \mathrm{ml})$ inhibited in a concentration-manner the release of CXCL8 (Fig. 3A), IL-6 (Fig. 3B) and TNF- $\alpha$ (Fig. 3C) induced by characellide A, from PBMC. Similar results were observed when we stimulated our positive control with simplexide (Fig. 3A-C). Conversely. DPPE-PEG had no effects on LPS-induced CXCL8, IL-6 and TNF- $\alpha$ release (Fig. 3 A-C) supporting the specificity of the inhibitory effect of DPPE-PEG linked to CD1d blocking. ods. CXCL8 (A), IL-6 (B) and TNF- $\alpha(\mathbf{C})$ in the supernatants were determined by ELISA. Data are the mean \pm SEM of five independent experiments. CXCL8 (D), IL6 (E) and TNF $\alpha(\mathbf{F})$ mRNA expression was analyzed by real-time PCR (see Methods) and values were normalized to GAPDH and expressed as $2^{-\triangle \mathrm{Ct}}$. Data are the mean \pm SEM of five independent experiments obtained from different donors. $* p<0.05, * * p<0.01, * * * p<0.001$

\section{Characellide-A and ROS production from PBMC}

Characellide A and B have been shown to inhibit ROS production from microglia cells (Afoullouss et al. 2019). Based on this study, we first investigated the effect of characellide A, B and LPS on ROS production in human PBMC. Figure 4A, C illustrates the kinetics profile (up to $50 \mathrm{~min}$ ) of the production of ROS induced by the control medium, characellide A and B or LPS. LPS induced ROS production by $\mathrm{PBMC}$ whereas, in contrast, characellide A and B had no effect. To evaluate whether characellide $\mathrm{A}$ and $\mathrm{B}$ were able to inhibit ROS production induced by LPS, we preincubated $\left(37^{\circ} \mathrm{C}, 5 \% \mathrm{CO}_{2}, 1 \mathrm{~h}\right)$ cells with characellide $\mathrm{A}$ or $\mathrm{B}$ and then stimulated $(10 \mathrm{~min})$ them with LPS. Figure 4B, D demonstrates that LPS-induced ROS production in PBMC was not influenced by characellide $\mathrm{A}$ and $\mathrm{B}$ stimulation. 

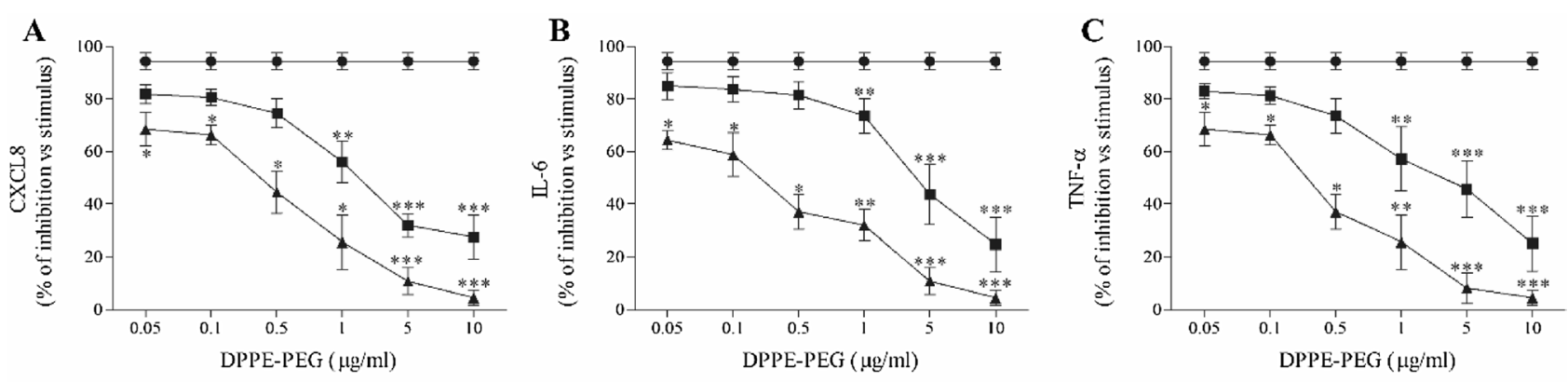

$\rightarrow$ LPS $\rightarrow$ Simplexide $\leftarrow$ Characellide A

Fig. 3 Effect of DPPE-PEG on characellide A-induced CXCL8, IL-6, and TNF- $\alpha$ release from PBMC. PBMC were preincubated $\left(37{ }^{\circ} \mathrm{C}\right.$, $\left.5 \% \mathrm{CO}_{2}, 30 \mathrm{~min}\right)$ with medium alone, or with the indicated concentrations of DPPE-PEG and then stimulated $(16 \mathrm{~h})$ with LPS (closed circle; $100 \mathrm{ng} / \mathrm{ml}$ ), simplexide (closed square; $10 \mu \mathrm{g} / \mathrm{ml}$ ) and characellide A (closed traingle; $10 \mu \mathrm{g} / \mathrm{ml}$ ). At the end of incubation the supernatants were collected and centrifuged $\left(300 \times g, 4{ }^{\circ} \mathrm{C}, 5 \mathrm{~min}\right)$. CXCL8 (A), IL-6 (B) and TNF- $\alpha(\mathbf{C})$ in the supernatants were determined by

\section{Discussion}

In this study, the marine glycolipopetide characellide A was shown to induce the expression and release of cytokines and chemokines from human peripheral blood mononuclear cells. A is stronger in inducing CXCL8 production than IL- 6 and TNF- $\alpha$. This compound exerts comparable effects to simplexide, a simpler glycolipid also isolated from a marine sponge, in releasing CXCL8 and TNF- $\alpha$ (Loffredo et al. 2014). Moreover, the stimulatory activity of characellide $\mathrm{A}$ is not inhibited by polymyxin B suggesting that it is really due to the natural molecule rather than traces of lipopolysaccharide, a well-known PBMC stimulus (Jansky et al. 2003; Loffredo et al. 2014). The effects of characellide $A$ on PBMC are mediated by CD1d expression on human PBMC.

Cellular activation could induce the release of preformed and/or de novo synthesized mediators. The release of CXCL8, IL- 6 and TNF- $\alpha$ induced by characellide A is timedependent requiring at least $8 \mathrm{~h}$ of stimulation. Therefore, the effects of characellide A are mediated by the induction of gene transcription. Indeed, characellide A activates the expression of $C X C L 8, I L 6$ and $T N F \alpha$ but not $I L-10$ mRNA, a gene which transcription is induced by simplexide in monocytes (Loffredo et al. 2014). However, a small albeit not significant release of IL-10 is induced by characellide A. Moreover, fresh lysated PBMC did not contain preformed CXCL8, IL-6, TNF- $\alpha$ and IL-10 supporting the evidence that the production of these mediators is only mediated by gene transcription.

The profile of cytokines/chemokines induced by characellide A in PBMC suggests that this compound may potentially exert both proinflammatory and immunoregulatory
ELISA. Data are expressed as percent of inhibition of the maximum response induced by LPS, characellide A or simplexide alone calculated as $\left(R-R_{\mathrm{b}}\right) /\left(R_{\max }-R_{\mathrm{b}}\right) \times 100$, where $R$ is the release in samples treated with the agonists plus DPPE-PEG, $R_{\mathrm{b}}$ is the release in unstimulated samples and $R_{\max }$ is the release in samples stimulated with agonist alone. Data are the mean \pm SEM of five experiments obtained from different donors. The lines represent the best fit for inhibition of LPS, characellide or simplexide. ${ }^{*} p<0.05,{ }^{*} p<0.01,{ }^{* * *} p<0.001$

activities. Both CXCL8 and TNF- $\alpha$ are potent inflammation molecules and are involved in recruitment and activation of inflammatory cells (Turner et al. 2014). On the other hand, IL-6 is a regulatory mediator (Tanaka et al. 2014) that can at least partially unfold the immunosuppressive function previously demonstrated by characellide A on BV-2 microglia cell activation (Afoullouss et al. 2019). In particular, characellide A inhibited ROS production in BV-2 microglia cells induced by LPS (Afoullouss et al. 2019). Here, we have repeated the same experiments on PBMC obtaining different results. LPS induced ROS production by PBMC but this effect is not inhibited by characellide A indicating that this molecule exerts a different effect depending on the cell. Interestingly, the inhibition of ROS production in LPS-stimulated microglia cells was induced by both characellide A and B (Afoullouss et al. 2019). By contrast, here we demonstrated that ROS production in LPS-stimulated PBMC was not inhibited by both characellide A and $\mathrm{B}$. The difference in bioactivity for both characellides is intriguing as they are epimers and only differ from the configuration at one chiral center of the sugar unit. The 2-amino-2-deoxyglucuronamide of characellide $\mathrm{A}$ is replaced by a 2-amino-2-deoxygalacturonamide for characellide B. The $S$ configuration at position C-4 of the sugar unit seems to be an important structural feature to enhance the bioactivity.

In fact, unlike the results on microglia cells, our results support the hypothesis that the structural differences between characellide $\mathrm{A}$ and $\mathrm{B}$ are enough to have a different activatory effect on PBMC. Converse to characellide $\mathrm{A}$, characellide $\mathrm{B}$ was unable to activate the cytokine and chemokine production by PBMC at any concentration tested.

Many natural molecules are modulators of innate and adaptive immunity (Fujii et al. 2006; Loffredo et al. 2014; 

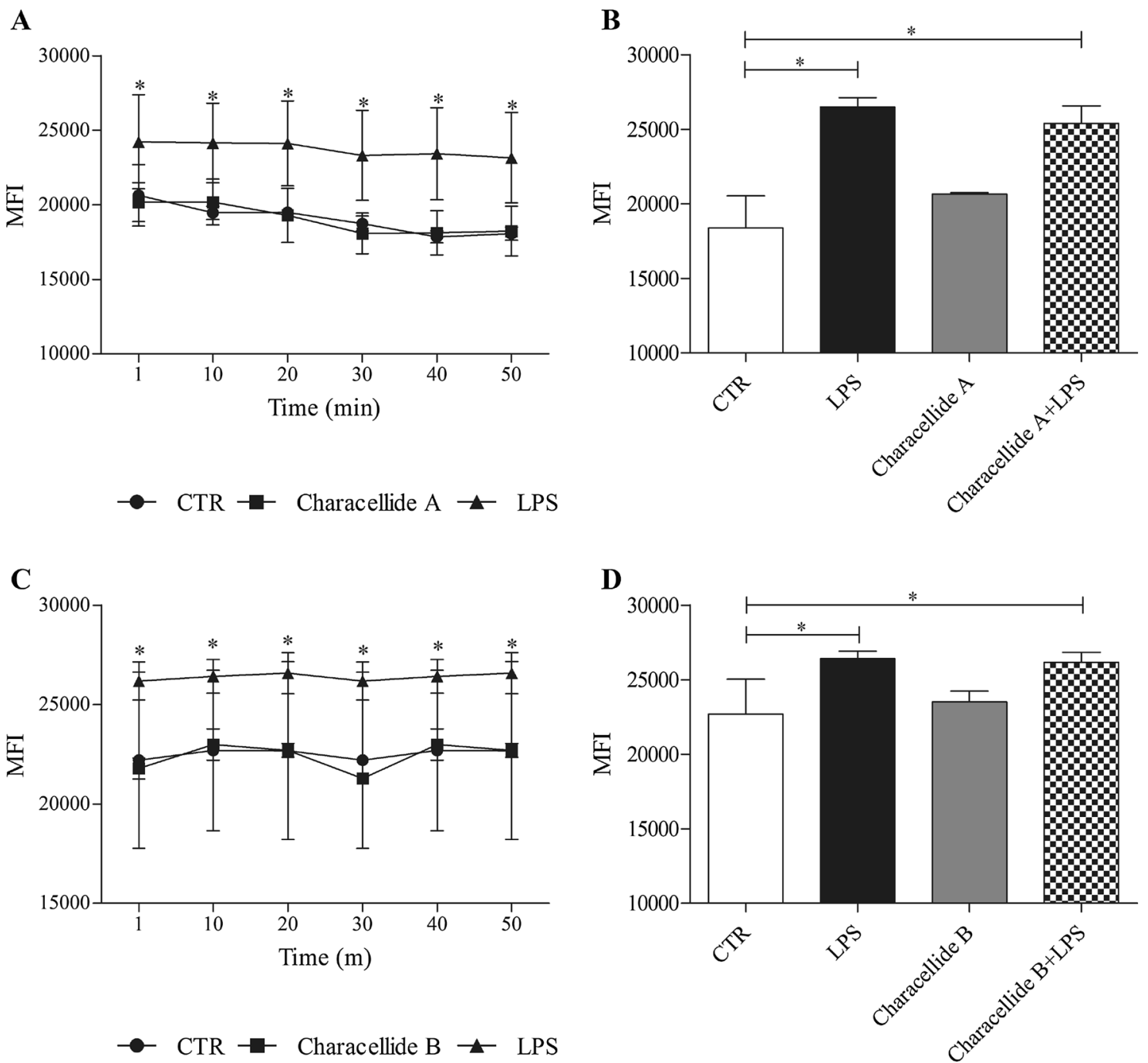

Fig. 4 Effect of Characellide A and Characellide B on ROS production from PBMC. PBMC were preincubated $\left(37^{\circ} \mathrm{C}, 5 \% \mathrm{CO}_{2}, 30 \mathrm{~min}\right)$ with $2^{\prime}, 7^{\prime}$-dichlorodihydrofluorescein diacetate $\left(\mathrm{H}_{2}\right.$ DCFDA, $\left.10 \mu \mathrm{M}\right)$, washed, and the added to precoated plates coated with methanol alone, Characellide A $(10 \mu \mathrm{g} / \mathrm{ml})$ (A), Characellide B $(10 \mu \mathrm{g} / \mathrm{ml})$ $(\mathbf{C})$, or stimulated with LPS alone $(\mathbf{A}, \mathbf{C})$. In panels $\mathbf{B}$ and $\mathbf{D}$, cells were preincubated $(1 \mathrm{~h})$ with Characellide A and Characellide B then

Amèlie Roux et al. 2019). Some metabolites extracted from marine sponges, such as $\alpha$-GalCer and simplexide, function as antigens primarily by interacting with CD1d expressed on immune cells including monocytes and lymphocytes (Berntman et al. 2005; Patel et al. 2011; Loffredo et al. 2014). We found that characellide A activity, akin to simplexide activity, is dependent on the interaction with CD1d because it is completely inhibited by a potent CD1d antagonist.

Canonically, the presentation of CD1d-bound molecules to natural killer T (NKT) cells activates cytokine/chemokine production in both NKT cells and subsequently in antigenpresenting cells (Gordon and Galli 1990; Barral and Brenner 2007; Venkataswamy et al. 2009; Zhang et al. 2011).

stimulated with LPS. Immediately after the stimulation, the cells were placed in a multimode microplate reader (EnSpire Multimode Plate reader, PerkinElmer), and DCF fluorescence intensity was quantitatively measured for $50 \mathrm{~min}(\mathbf{A}, \mathbf{C})$ or at $10 \mathrm{~min}(\mathbf{B}, \mathbf{D})$. The results were expressed as mean fluorescence intensity (mean \pm SEM of five independent experiments obtained from different donors). $* p<0.05$

Previously we demonstrated that simplexide can itself generate intracellular signals directly by interaction with CD1d. Therefore the presence of NKT cells was not mandatory for simplexide-induced cytokine production from monocytes (Loffredo et al. 2014). A limit of our study is that it is conducted on PBMC. PBMC are any peripheral blood cell having a round nucleus. These cells consist of lymphocytes ( $\mathrm{T}$ and $\mathrm{B}$ cells, NK cells) and monocytes, therefore, a question that remains to be answered is which cells belonging to PBMC are directly or indirectly activated by characellide A. It will be interesting to assess the effect of characellide A on purified cell populations of PBMC, in particular monocytes, to better understand its cellular activation mechanism. 
In conclusion, characellide $\mathrm{A}$ is a novel and potent stimulus for cytokine and chemokine production in human PBMC. Our data suggest that this molecule behaves as a "danger" signal and may be involved in the activation of adaptative/ innate immune responses. Further studies with purified cells are required to fully understand biological activity of characellide.

Since some of the sponge-derived metabolites were included in clinical and preclinical trials showing their efficacy as modulators of immune response (Gunasekera et al. 1989; Alcaraz and Paya 2006; Fattorusso and TaglialatelaScafati 2009; Sagar et al. 2010; Bibi et al. 2017; Negi et al. 2017; Karpinski 2019; Yurchenko et al. 2020), the observation that characellide $A$ is a potent in vitro activator of $\mathrm{PBMC}$ raising interesting perspectives on its potential pharmacological application.

Acknowledgements We would like to thank Dr. Gjada Criscuolo for critical reading of the manuscript and the administrative staff (Dr. Roberto Bifulco and Dr. Anna Ferraro), without whom it would not be possible to work as a team.

Author contributions The concept and idea of this project were designed by Prof. SL, Prof. OPT, Prof. LA and Prof. PVM. Methodology and research work was developed by Dr. SM and Dr. SA under the supervision of Prof. SL and Prof. LA and OPT respectively, writing of original draft was done by Dr. SM, SA, Prof. SL, Prof. LA and Prof. OPT and Prof. PVM.

Funding Open access funding provided by Università degli Studi di Napoli Federico II within the CRUI-CARE Agreement. This work was supported in part by grants from the CISI-Lab Project (University of Naples Federico II), TIMING Project and Campania Bioscience (Regione Campania). SA and ALA are supported by Science Foundation Ireland and the Marine Institute under the Investigators Programme Grant Number SFI/15/IA/3100 co-funded under the European Regional Development Fund 2014-2020.

\section{Declarations}

Conflict of interest The authors declare that they have no competing interest.

Ethical approval This study has received ethical, regulatory and institutional approvals at Ethics Committee of the University of Naples Federico II (protocol number 301/12), and was run in accordance with the recommendations from the Declaration of Helsinki.

Consent to participate All the authors gave consent as a participant in this study.

Consent for publication All the authors gave consent for the publication of this study in your journal.

Open Access This article is licensed under a Creative Commons Attribution 4.0 International License, which permits use, sharing, adaptation, distribution and reproduction in any medium or format, as long as you give appropriate credit to the original author(s) and the source, provide a link to the Creative Commons licence, and indicate if changes were made. The images or other third party material in this article are included in the article's Creative Commons licence, unless indicated otherwise in a credit line to the material. If material is not included in the article's Creative Commons licence and your intended use is not permitted by statutory regulation or exceeds the permitted use, you will need to obtain permission directly from the copyright holder. To view a copy of this licence, visit http://creativecommons.org/licenses/by/4.0/.

\section{References}

Afoullouss S, Calabro K, Genta-Jouve G, Gegunde S, Alfonso A, Nesbitt R, Morrow C, Alonso E, Botana LM, Allcock AL, Thomas OP (2019) Treasures from the deep: characellides as anti-inflammatory lipoglycotripeptides from the sponge Characella pachastrelloides. Org Lett 21(1):246-251

Alcaraz MJ, Paya M (2006) Marine sponge metabolites for the control of inflammatory diseases. Curr Opin Investig Drugs 7(11):974-979

Amèlie Roux SL, Ferrara AL, Murphy PV (2019) Synthesis and biological evaluation of S-simplexides and other analogues of simplexide. Pure Appl Chem 91:1257-1276

Anjum K, Abbas SQ, Shah SA, Akhter N, Batool S, Hassan SS (2016) Marine sponges as a drug treasure. Biomol Ther (seoul) 24(4):347-362

Barral DC, Brenner MB (2007) CD1 antigen presentation: how it works. Nat Rev Immunol 7(12):929-941

Berntman E, Rolf J, Johansson C, Anderson P, Cardell SL (2005) The role of CD1d-restricted NK T lymphocytes in the immune response to oral infection with Salmonella typhimurium. Eur J Immunol 35(7):2100-2109

Bibi F, Faheem M, Azhar EI, Yasir M, Alvi SA, Kamal MA, Ullah I, Naseer MI (2017) Bacteria from marine sponges: a source of new drugs. Curr Drug Metab 18(1):11-15

Blunt JW, Copp BR, Munro MH, Northcote PT, Prinsep MR (2006) Marine natural products. Nat Prod Rep 23(1):26-78

Brigl M, Brenner MB (2004) CD1: antigen presentation and T cell function. Annu Rev Immunol 22:817-890

Canchis PW, Bhan AK, Landau SB, Yang L, Balk SP, Blumberg RS (1993) Tissue distribution of the non-polymorphic major histocompatibility complex class I-like molecule, CD1d. Immunology 80(4):561-565

Exley M, Garcia J, Wilson SB, Spada F, Gerdes D, Tahir SM, Patton KT, Blumberg RS, Porcelli S, Chott A, Balk SP (2000) CD1d structure and regulation on human thymocytes, peripheral blood T cells, B cells and monocytes. Immunology 100(1):37-47

Fattorusso E, Taglialatela-Scafati O (2009) Marine antimalarials. Mar Drugs 7(2):130-152

Faulkner DJ (2000) Marine natural products. Nat Prod Rep 17(1):7-55

Faulkner DJ (2001) Marine natural products. Nat Prod Rep 18(1):1-49

Faulkner DJ (2002) Marine natural products. Nat Prod Rep 19(1):1-48

Fujii S, Shimizu K, Hemmi H, Fukui M, Bonito AJ, Chen G, Franck RW, Tsuji M, Steinman RM (2006) Glycolipid alpha-C-galactosylceramide is a distinct inducer of dendritic cell function during innate and adaptive immune responses of mice. Proc Natl Acad Sci USA 103(30):11252-11257

Gordon JR, Galli SJ (1990) Mast cells as a source of both preformed and immunologically inducible TNF-alpha/cachectin. Nature 346(6281):274-276

Gunasekera SP, Cranick S, Longley RE (1989) Immunosuppressive compounds from a deep water marine sponge, Agelas flabelliformis. J Nat Prod 52(4):757-761

Hertiani T, Edrada-Ebel R, Ortlepp S, van Soest RW, de Voogd NJ, Wray V, Hentschel U, Kozytska S, Muller WE, Proksch P (2010) 
From anti-fouling to biofilm inhibition: new cytotoxic secondary metabolites from two Indonesian Agelas sponges. Bioorg Med Chem 18(3):1297-1311

Jansky L, Reymanova P, Kopecky J (2003) Dynamics of cytokine production in human peripheral blood mononuclear cells stimulated by LPS or infected by Borrelia. Physiol Res 52(6):593-598

Karpinski TM (2019) Marine macrolides with antibacterial and/or antifungal activity. Mar Drugs 17(4):241

Kawano T, Cui J, Koezuka Y, Toura I, Kaneko Y, Motoki K, Ueno H, Nakagawa R, Sato H, Kondo E, Koseki H, Taniguchi M (1997) CD1d-restricted and TCR-mediated activation of valpha14 NKT cells by glycosylceramides. Science 278(5343):1626-1629

Koch M, Stronge VS, Shepherd D, Gadola SD, Mathew B, Ritter G, Fersht AR, Besra GS, Schmidt RR, Jones EY, Cerundolo V (2005) The crystal structure of human CD1d with and without alphagalactosylceramide. Nat Immunol 6(8):819-826

Kolomaznik M, Liskayova G, Kanjakova N, Hubcik L, Uhrikova D, Calkovska A (2018) The perturbation of pulmonary surfactant by bacterial lipopolysaccharide and its reversal by polymyxin B: function and structure. Int J Mol Sci 19(7):1964

Kronenberg M (2005) Toward an understanding of NKT cell biology: progress and paradoxes. Annu Rev Immunol 23:877-900

Lexmond WS, Neves JF, Nurko S, Olszak T, Exley MA, Blumberg RS, Fiebiger E (2014) Involvement of the iNKT cell pathway is associated with early-onset eosinophilic esophagitis and response to allergen avoidance therapy. Am J Gastroenterol 109(5):646-657

Loffredo S, Staiano RI, Granata F, Costantino V, Borriello F, Frattini A, Lepore MT, Mangoni A, Marone G, Triggiani M (2014) Simplexide induces CD1d-dependent cytokine and chemokine production from human monocytes. PLoS ONE 9(11):e111326

Mars LT, Gautron AS, Novak J, Beaudoin L, Diana J, Liblau RS, Lehuen A (2008) Invariant NKT cells regulate experimental autoimmune encephalomyelitis and infiltrate the central nervous system in a CD1d-independent manner. J Immunol 181(4):2321-2329

Mehbub MF, Lei J, Franco C, Zhang W (2014) Marine sponge derived natural products between 2001 and 2010: trends and opportunities for discovery of bioactives. Mar Drugs 12(8):4539-4577

Negi B, Kumar D, Rawat DS (2017) Marine peptides as anticancer agents: a remedy to mankind by nature. Curr Protein Pept Sci 18(9):885-904

Ni C, Wu P, Wu X, Zhang T, Zhang T, Wang Z, Zhang S, Qiu F, Huang J (2015) Thymosin alpha1 enhanced cytotoxicity of iNKT cells against colon cancer via upregulating CD1d expression. Cancer Lett 356(2 Pt B):579-588

Patel O, Cameron G, Pellicci DG, Liu Z, Byun HS, Beddoe T, McCluskey J, Franck RW, Castano AR, Harrak Y, Llebaria A, Bittman
R, Porcelli SA, Godfrey DI, Rossjohn J (2011) NKT TCR recognition of CD1d-alpha- $C$-galactosylceramide. J Immunol 187(9):4705-4713

Sagar S, Kaur M, Minneman KP (2010) Antiviral lead compounds from marine sponges. Mar Drugs 8(10):2619-2638

Sipkema D, Franssen MC, Osinga R, Tramper J, Wijffels RH (2005) Marine sponges as pharmacy. Mar Biotechnol (NY) 7(3):142-162

Skold M, Behar SM (2003) Role of CD1d-restricted NKT cells in microbial immunity. Infect Immun 71(10):5447-5455

Tanaka T, Narazaki M, Kishimoto T (2014) IL-6 in inflammation, immunity, and disease. Cold Spring Harb Perspect Biol 6(10):a016295

Thomas TR, Kavlekar DP, LokaBharathi PA (2010) Marine drugs from sponge-microbe association-a review. Mar Drugs 8(4):1417-1468

Turner MD, Nedjai B, Hurst T, Pennington DJ (2014) Cytokines and chemokines: at the crossroads of cell signalling and inflammatory disease. Biochim Biophys Acta 1843(11):2563-2582

Venkataswamy MM, Baena A, Goldberg MF, Bricard G, Im JS, Chan J, Reddington F, Besra GS, Jacobs WR Jr, Porcelli SA (2009) Incorporation of NKT cell-activating glycolipids enhances immunogenicity and vaccine efficacy of Mycobacterium bovis bacillus Calmette-Guerin. J Immunol 183(3):1644-1656

Vintonyak VV, Cala M, Lay F, Kunze B, Sasse F, Maier ME (2008) Synthesis and biological evaluation of cruentaren A analogues. Chemistry 14(12):3709-3720

Wu D, Fujio M, Wong CH (2008) Glycolipids as immunostimulating agents. Bioorg Med Chem 16(3):1073-1083

Yurchenko EA, Kolesnikova SA, Lyakhova EG, Menchinskaya ES, Pislyagin EA, Chingizova EA, Aminin DL (2020) Lanostane triterpenoid metabolites from a Penares sp. marine sponge protect neuro-2a cells against paraquat neurotoxicity. Molecules 25(22):5397

Zhang B, Alysandratos KD, Angelidou A, Asadi S, Sismanopoulos N, Delivanis DA, Weng Z, Miniati A, Vasiadi M, Katsarou-Katsari A, Miao B, Leeman SE, Kalogeromitros D, Theoharides TC (2011) Human mast cell degranulation and preformed TNF secretion require mitochondrial translocation to exocytosis sites: relevance to atopic dermatitis. J Allergy Clin Immunol 127(6):1522-1531

Publisher's Note Springer Nature remains neutral with regard to jurisdictional claims in published maps and institutional affiliations. 